\title{
ASSOCIAÇÃO BRASILEIRA DE ENFERMAGEM RESOLUÇÕES DA ASSEMBLÉIA DE DELEGADOS* A ASSEMBLÉIA DE DELEGADOS DA ABEn
}

\section{CONSIDERANDO}

1 - que as atuais condições econômicas do País comportam a elevação do nível salarial das enfermeiras;

2 - (a) que a transferência da sede da ABEn para o Distrito Federal é imperativa;

(b) que de acordo com 0 s $1 .^{\circ}$, do Art. $1 .^{\circ}$ dos Estatuto da ABEn, de tempo de duração indeterminado, tem provisoriamente. Sede e fôro na cidade do Rio de Janeiro, GB.

3 - (a) que o mandato dos membros da Diretoria é de 4 anos e o das Coordenadoras de Comissões é de 2 anss;

(b) que a mudança de Coordenadoras no meio do mandato de Diretoria causa discontinuidade dos trabalhos.

\section{DELIBERA}

1 - que a ABEn reitere aos poderes competentes, solicitação para ser estabelecido o salário mínimo profissional e jornada de trabalho para o enfermeiro.

2 - que o $\$ 1 .^{\circ}$, do Art. $1 .^{\circ}$ dos Estatutos tenha a seguin-. te redação:

A ABEn, de tempo de duração indeterminado, tem Sede e fôro no Distrito Federal.
3 - que o $\$ 1 .^{\circ}$, do Art. 32 te- nha a seguinte redação: O mandato das Coordena- doras de Comissões será. de 4 anos.

\footnotetext{
* Realizada em João Pessoa, PB, no dia 16 de julho de 1973.
} 